Volume 9. No. 5, May 2021

International Journal of Emerging Trends in Engineering Research

Available Online at http://www.warse.org/IJETER/static/pdf/file/ijeter06952021.pdf

https://doi.org/10.30534/ijeter/2021/06952021

\title{
Assessment of Physico-Chemical Characteristics of Wastewater from Dairy industry
}

\author{
Dr.Dhanasekar. $\mathbf{K}^{1}$, Dinesh.R ${ }^{2}$, Naveen. $K^{2}$, Sanjay Krsihna. $\mathbf{S}^{2}$, Ragavendar. $\mathbf{K}^{2}$ \\ ${ }^{1}$ Professor, Department of Civil Engineering, Panimalar Engineering College, Chennai, India \\ ${ }^{2}$ Students, Department of Civil Engineering, Panimalar Engineering College, Chennai, India
}

\begin{abstract}
The present work is aimed to analyze Physico-Chemical parameters of wastewater effluent from a dairy industry in Chennai. The dairy industry which was taken for study purpose involves processing of raw milk into products like consumer milk, butter, cheese, ice-cream's and other milk products. Considering the increased milk demand, the dairy industry in India is expected to grow speedily and have the waste generation and related ecological problems are also assumed increased importance. An attempt has been made to study the Physico-chemical characteristics of waste water generated from dairy industry near Chennai in Tamilnadu state of India. Waste water samples were collected from the dairy industry and analyzed for $\mathrm{pH}, \mathrm{EC}, \mathrm{TSS}, \mathrm{NO}_{3^{-}}, \mathrm{PO}_{4}, \mathrm{Cl}-$, $\mathrm{Fe}, \mathrm{BOD}, \mathrm{COD}$, oil \& grease.
\end{abstract}

Keywords: Dairy industry, Demand, India, Physico-Chemical parameters, Waste water

\section{INTRODUCTION}

With the rapid industrialization witnessed in the last era and the growing rate of milk production (around 2.8\% per annum), dairy processing is usually considered to be the largest industrial food wastewater source to environment. Developmental activities in major sectors such as industries, transportation and agriculture are polluting the natural and subsurface water bodies $[4,5]$. Water resource is considered as one of the most important strategic resource for economic development of any country $[2,3]$. Hence it is need of the hour to treat any industrial effluent as per the standards, before disposing it in any water bodies.

Wastewater from dairy industries contains huge quantities of fat, casein, lactose, and inorganic salts, besides cleansing agent, disinfectants etc used for washing [10]. The above parameters contribute largely towards their high biological oxygen demand (BOD), chemical oxygen demand (COD) and oil and grease are much higher than the permissible limits [1]. According to Kushwa et al 2011, the Dairy industry wastewaters contain suspended and dissolved solids, soluble and trace organics, nutrients, fats, chlorides, sulphate, lactose, and they are described by high chemical oxygen demand (COD) and biological oxygen demand (BOD) [11].

Regional pollution control authorities are applying more pressure on industries to reduce their organic BOD and chemical oxygen demand (COD) and solids loading to the sewers [12]. Dairy and Food processing wastewaters are particularly targeted because of the high BOD concentrations typically contained, especially high-strength wastewaters with high levels of suspended solids, ammonia and protein compounds [9]. Apart from above the Dairy industries are considered as the most environmentally unfriendly processes, because they produce wastewater that contains suspended solids. The discharge of this water into aquatic bodies affects aquatic life and the water quality.

Treatments of dairy wastewaters contains the application of mechanical, physicochemical and biological methods. Mechanical treatment is necessary to equalize volumetric and mass flow changes. It also reduces parts of the 
Dhanasekar. K et al., International Journal of Emerging Trends in Engineering Research, 9(5), May 2021, 570 - 575

suspended solids. Physicochemical processes are effective in the removal of mixed compounds, but reagent addition increases water treatment costs [7]. Therefore, biological wastewater treatment systems are preferred due to the highly decomposable contaminants.

Hence of the three specified above methods, the authors had made an attempt to analyze the Physico-chemical characteristics of waste water generated from dairy industry

\section{MATERIALS AND METHODS}

Waste water samples were collected from a discharge point directly in alternative months during the year 2020 and continued till March 2021. The samples has been collected periodically in a closed white can and numbered accordingly. Special treatments were given for preservation, fixation and management of water samples before analysis in order to prevent the change in parameters of the sample. The chemical analysis and testing of the samples is carried out in laboratory in a controlled environment.

The waste water samples were analyzed immediately for hydrogen ion concentration $(\mathrm{pH})$ using $\mathrm{pH}$ meter, Electrical conductivity using EC meter. Coagulation and flocculation processes are used basically to separate suspended, colloidal and dissolved contents from wastewater and they applied directly to raw wastewater. Chloride $(\mathrm{Cl})$ ) was determined titrimetrically by standard $\mathrm{AgNO}_{3}$ titration. Phosphate $\left(\mathrm{PO}_{4}\right.$

${ }^{-3}$ ) were analyzed, using spectrophotometer. Apart from above test, BOD and COD test also conducted for the collected samples in the laboratory using standard procedures [8]. All parameters are expressed in milligrams per litre $(\mathrm{mg} / \mathrm{l})$ and mill equivalents per litre (meq/l), except $\mathrm{pH}$ and $\mathrm{EC}$.

\section{RESUltS AND DisCUSSION}

The analysis of waste water samples is presented in Table-1. The wastewater parameters variation during different period is presented graphically in Figure-1 to Figure-10.

pH: The values of $\mathrm{pH}$ was found to be in the range from 6.3 to 6.6 and are within the permissible limit for most of the Samples collected in various months. The average value for
$\mathrm{pH}$ works out to 6.39 which in $76 \%$ of the limiting value of 8.5. It is evident that a very low standard deviation of 0.11 indicates that the various $\mathrm{pH}$ values measured during different months tends to be very close to the mean. Further it has been seen that the $\mathrm{pH}$ values are slowly and steadily increasing especially in summer months, implying the presence of nutrients, high organic load and use of alkaline cleaning agents in dairy industry lead to its alkaline $\mathrm{pH}$. The variation of $\mathrm{pH}$ for samples collected during different period is presented in Figure-1.

Nitrate: The average value of nitrates was found to be $31.1 \mathrm{mg} / \mathrm{l}$. which is found to be under permissible limit. Excess nitrate content in waste water can cause serious problems such as eutrophication of rivers and contamination of water sources and can have an adverse effect on human health. Hence, it has to be ensured properly before discharging in surface water sources [14]. The variation of nitrate for samples collected during different period is presented in Figure-2.

Phosphate: The mean value of phosphate content was found to be $2.2 \mathrm{mg} / \mathrm{l}$ which is found to be less as recommended by Indian standards and safe for discharging in surface water. The variation of phosphate for samples collected during different period is presented in Figure-3.

Total suspended Solids: TSS can include a wide variety of material, such as silt, decaying plant and animal matter, industrial wastes, and sewage. The total suspended solids in the current study was found to vary between $510 \mathrm{mg} / \mathrm{l}$ to $752 \mathrm{mg} / \mathrm{l}$. Rao et al has recommended that by using Coagulation process, it is possible to remove $94 \%$ TSS from the effluent $[6,15]$. Hence, the effluent is treated and bring to standards as recommended by IS before discharging in to inland surface water. The variation of TSS for samples collected during different period is presented in Figure-4.

Chloride: The permissible limit of chloride content as per WHO is $1000 \mathrm{mg} / \mathrm{l}$. But in most of the samples the $\mathrm{Cl}$ content is far less. On an average the $\mathrm{Cl}$ content is as low as $432 \mathrm{mg} / \mathrm{l}$. i.e. $43.2 \%$, whereas the highest is $47.5 \%$. Both the situations 
Dhanasekar. K et al., International Journal of Emerging Trends in Engineering Research, 9(5), May 2021, $570-575$

are not encouraging, meaning that we need to arrest the toxic effect of other chemical contents so as to improve the $\mathrm{Cl}$ effect. The variation of chlorides for samples collected during different period is presented in Figure-5.

BOD: Biochemical oxygen demand (BOD) is nothing but the amount of oxygen required by microorganisms, while stabilizing biological decomposable organic matter in a waste under aerobic conditions. The BOD of the effluent in the current study was found to be varying from 300 to $323 \mathrm{mg} / 1$.It is found to be safe if it has been discharged in sewers as the permissible limit for discharging in sewers as per IS is $350 \mathrm{mg} / 1$ [8]. If the effluent is discharged in inland surface water, then the waste has to treated further to bring it down to $30 \mathrm{mg} / \mathrm{l}$ as per IS recommendations. The variation of BOD for samples collected during different period is presented in Figure-6.

COD: The chemical oxygen demand test (COD) determines, the oxygen required for chemical oxidation of organic matter with the help of strong chemical oxidant. The COD is a test which is used to measure pollution of domestic and industrial waste. It is a fact that all organic compounds with a few exceptions can be oxidizing agents under the acidic condition. COD test is useful in identifying toxic condition and presence of biological resistant substances. For COD determination samples were preserved using $\mathrm{H}_{2} \mathrm{SO}_{4}$ and processed for COD determination after the entire sampling operation was complete. The COD of the effluent varied from 925 to 954 $\mathrm{mg} / \mathrm{l}$. Hence, the effluent is further treated and it has to be ensured that it has brought down to lesser than $250 \mathrm{mg} / \mathrm{l}$ before discharging into environment. The variation of COD for samples collected during different period is presented in Figure-7.

Salinity: The average Salinity value noted in dairy effluent was $1.4 \mathrm{mg} / \mathrm{l}$. Higher salinity values were due to increase in solubility of solids. The variation of salinity for samples collected during different period is presented in Figure-8.

Iron: The concentration of iron in waste water samples varies from 0.55 to $0.75 \mathrm{mg} / \mathrm{L}$ indicating the values of all the samples collected in different months are within the permissible limit. The removal of excess iron from water is by aeration followed by sedimentation is suggested for water having more concentration of iron. The variation of iron for samples collected during different period is presented in Figure-9.

Oil \& Grease: Oil and grease present in the effluent of dairy industry reduces dissolved oxygen when it is discharged directly in inland water bodies. Hence, it has to be ensured that it is within permissible limit of $10 \mathrm{mg} / \mathrm{l}$ as recommended by Indian standards. The oil and grease content in the effluent of the present study varies from $1 . \mathrm{mg} / \mathrm{l}$ to $2.3 \mathrm{mg} / \mathrm{l}$. The variation of oil \& grease for samples collected during different period is presented in Figure-10.

Specific conductance (EC): Specific conductance is a measure of salt content in the form of ions [13]. In the present study, the average EC value was to be $252 \mu-\mathrm{mho} / \mathrm{cm}$. As low EC values were recorded during the entire period, the water is found to be safe for discharging in surface water bodies or in any other environment.

Table 1: Physico Chemical analysis of waste water from Dairy Industry

\begin{tabular}{|l|l|l|l|l|}
\hline \multicolumn{1}{|c|}{ Parameter } & \multicolumn{1}{|c|}{$\begin{array}{c}\text { Range } \\
(\mathbf{m g} / \mathbf{l})\end{array}$} & \multicolumn{1}{c|}{ Mean } & \multicolumn{1}{c|}{$\boldsymbol{~}$} & \multicolumn{1}{c|}{ CV } \\
\hline $\mathrm{pH}($ no unit) & $6.3-6.6$ & 6.39 & 0.11 & 1.71 \\
\hline $\mathrm{NO}_{3}{ }^{-}$ & $30-36$ & 31.1 & 1.82 & 5.83 \\
\hline $\mathrm{PO}_{4}{ }^{3-}$ & $2.1-2.5$ & 2.28 & 0.14 & 6.14 \\
\hline $\mathrm{TSS}$ & $510-752$ & 629 & 81.4 & 13 \\
\hline Chlorides & $432-475$ & 445 & 16.6 & 3.73 \\
\hline BOD & $300-323$ & 314 & 7.14 & 2.46 \\
\hline COD & $925-954$ & 944 & 10.4 & 1.11 \\
\hline Salinity & $1.2-1.6$ & 1.4 & 0.17 & 12.1 \\
\hline Iron & $0.55-.75$ & 0.66 & 0.06 & 9.09 \\
\hline Oil \& Grease & $1.6-2.3$ & 1.98 & 0.24 & 2.31 \\
\hline EC $(\mu-m h o / c m)$ & $201-310$ & 252 & 44.5 & 17.7 \\
\hline
\end{tabular}


Dhanasekar. K et al., International Journal of Emerging Trends in Engineering Research, 9(5), May 2021, $570-575$

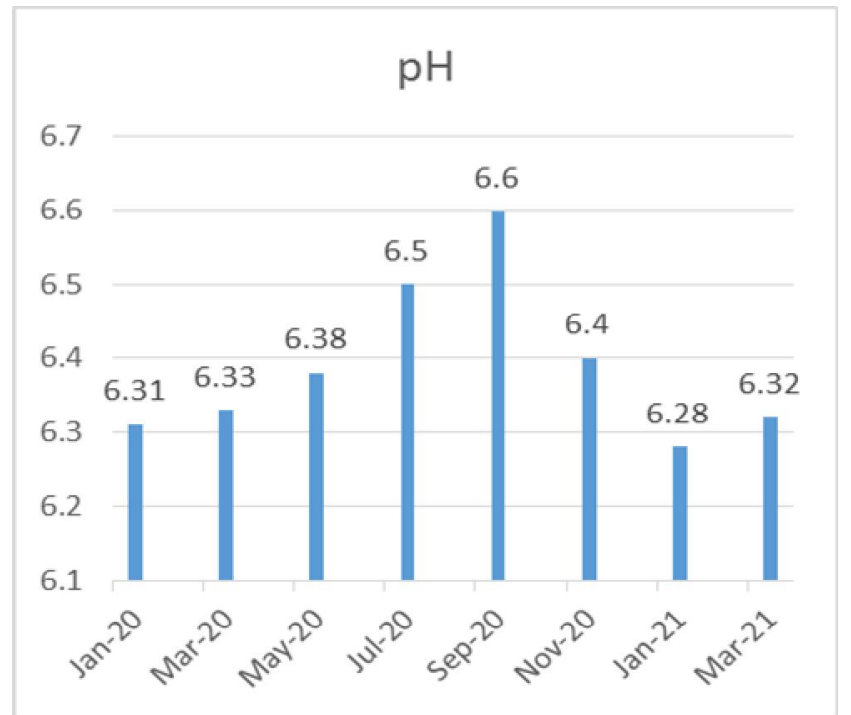

Figure-1 pH variation

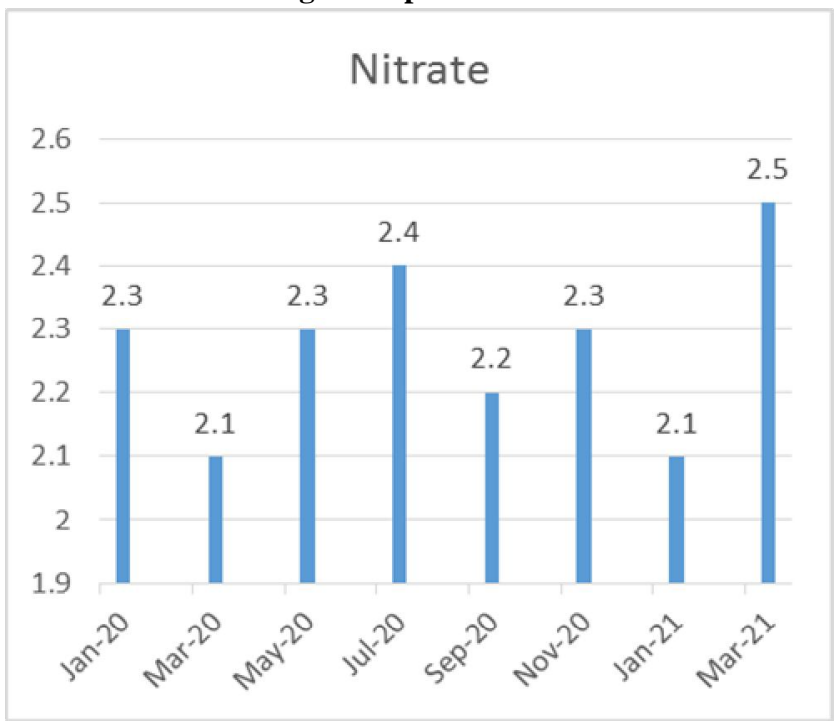

Figure-2 Nitrate variation

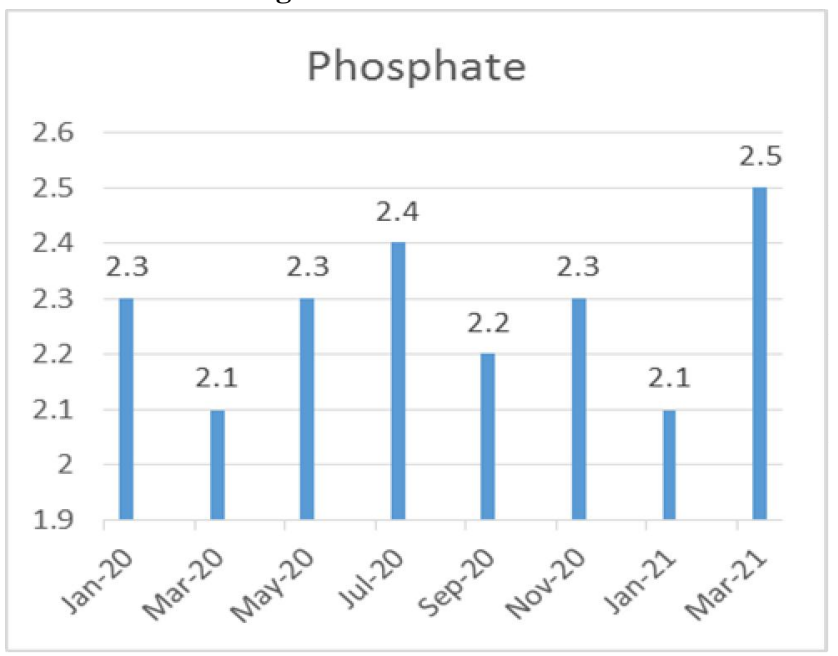

Figure-3 phosphate variation

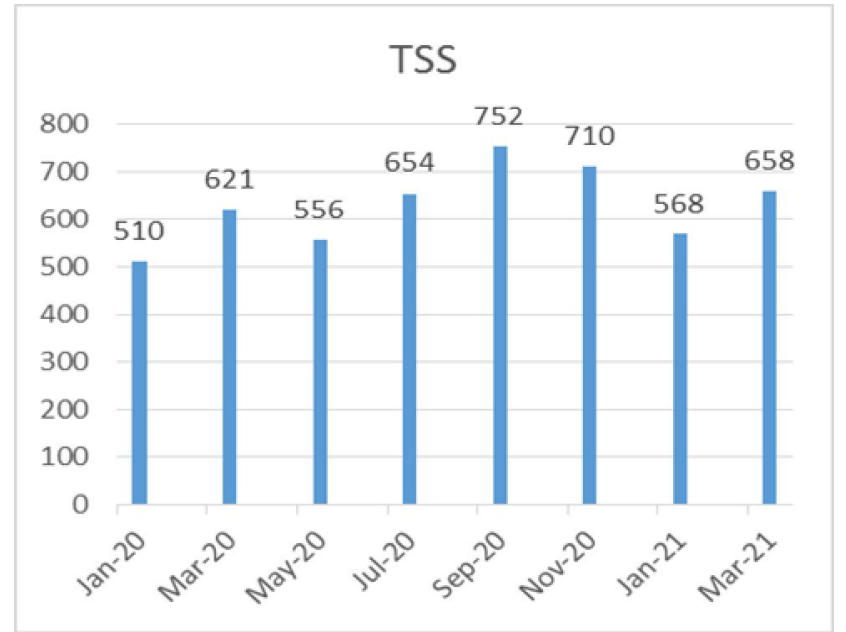

Figure-4 TSS variation

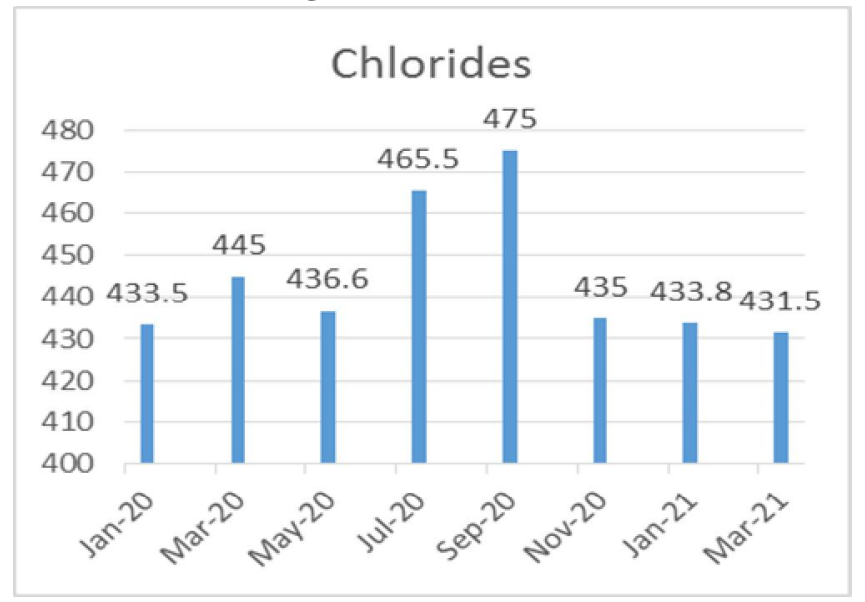

Figure-5 Chloride variation

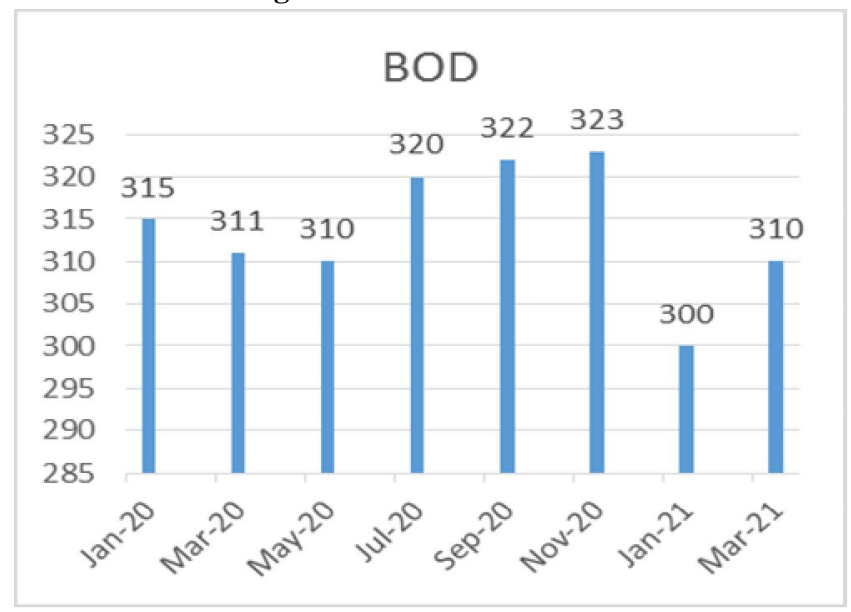

Figure-6 BOD variation 
Dhanasekar. K et al., International Journal of Emerging Trends in Engineering Research, 9(5), May 2021, 570 - 575
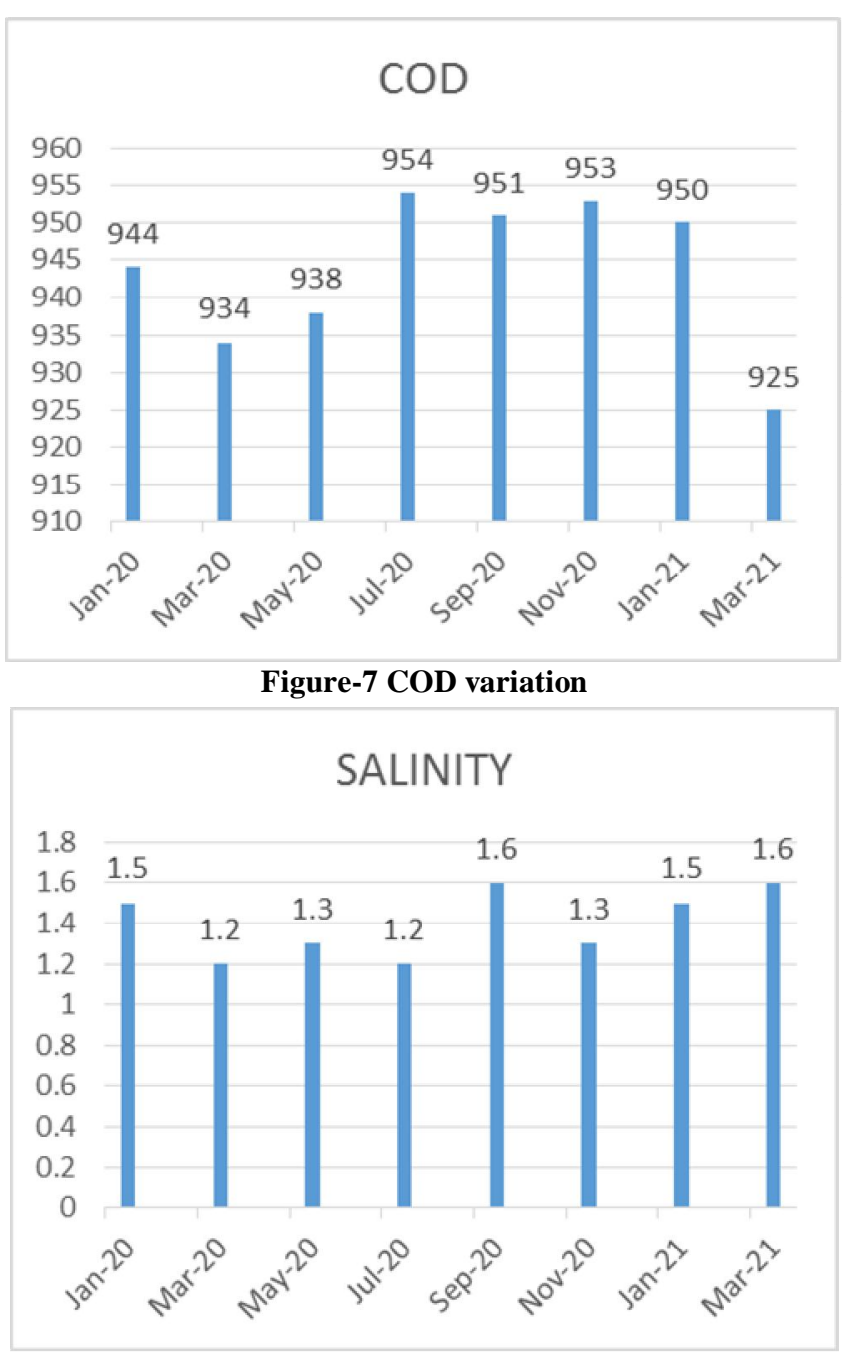

Figure-8 Salinity Variation

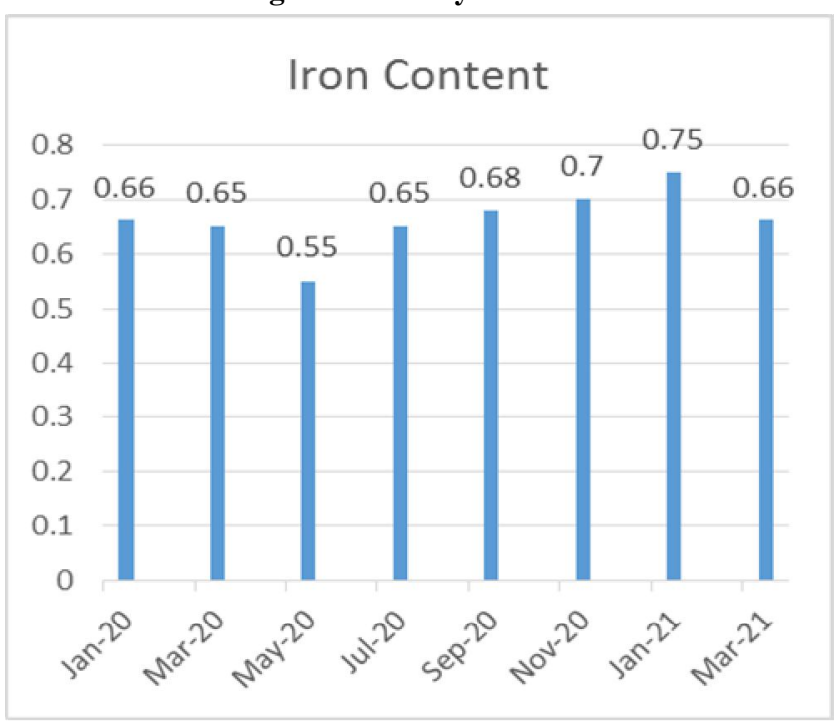

Figure-9 Iron variation

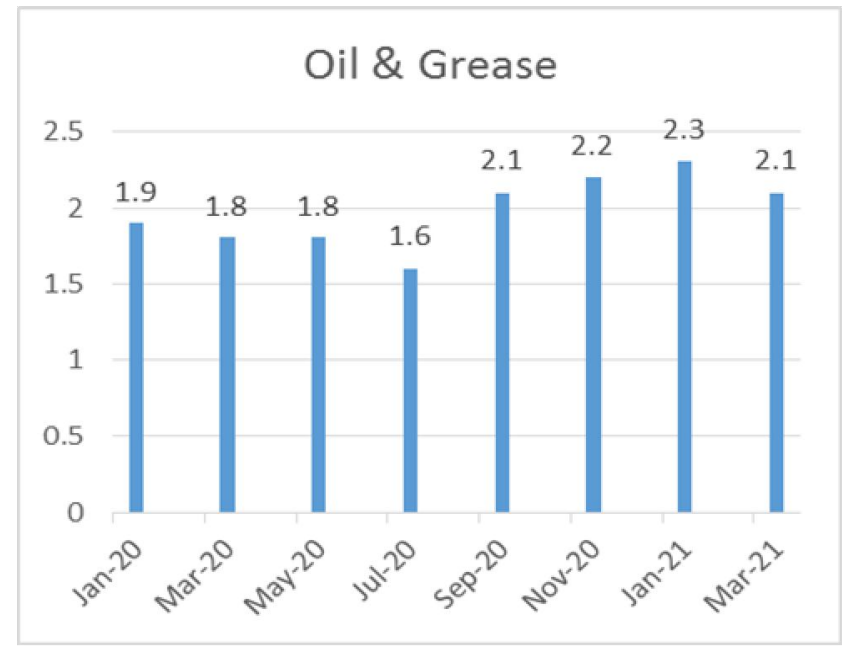

Figure-10 oil and Grease variation

\section{CONCLUSION}

The waste water samples collected from the study area in general is white in colour and slightly alkaline in nature with an average EC of $410 \mu \mathrm{mhos} / \mathrm{cm}$. Total suspended solids, phosphate, Nitrate, and EC of the collected samples are within permissible limit of BIS standards. However BOD and COD are found to be more than the prescribed standards. Hence it is recommended to treat if further using electrocoagulation process for arriving 98\% removal efficiency and made it fit for safer disposal in environment. Appendixes, if needed, appear before the acknowledgment.

\section{ACKNOWLEDGEMENT}

The authors thank Panimalar Engineering College, Affiliated to Anna University, Chennai for supporting us to utilize Institutional facilities to carry out research work in a Fruitful and efficient manner.

\section{REFERENCES}

1. Aagosh Verma and Anuradha Singh, Physico-Chemical Analysis of Dairy Industrial Effluent, Int.J.Curr.Microbiol.App.Sci, vol 6(7), (2017), pp. 1769-1775

2. Dhanasekar.K, Partheeban.P, "Numerical Modeling of Groundwater flow in Karayanchavadi region of Chennai, Tamilnadu, India”, Ecology 
Dhanasekar. K et al., International Journal of Emerging Trends in Engineering Research, 9(5), May 2021, 570 - 575

Environment and Conservation, Vol-23, (2017), PP-1564-1570.

3. Dhanasekar.K, Partheeban.P, “Water Quality Index for Groundwater in Chennai, Tamilnadu, India”, Pollution Research,vol-33, No.2, (2014), PP-327-335

4. Dhanasekar.K,Partheeban.P "Assessment of Physico-Chemical characteristics of ground water in Chennai", Nature Environment and Pollution Technology, Vol- 11, No.4, (2012), PP-705-709.

5. Garg et al. An Appraisal of Ground water Quality in some Villages of District Jind, Indian Journal for Environmental Protection. 19(4), (1999), pp$267-272$.

6. Girish,C.R, Sushant Kumar Singh, Suhas Shenoy, Removal of suspended solids from dairy wastewater using flocculation, International Journal of Mechanical Engineering and Technology, Volume 8, Issue 11, (2017), pp. 99-105.

7. Hung YT, Lo HH, Wang LK, Taricksa JR, Li KH. In: Wang LK, Hung YT, Shammas NK, editors. Granular activated carbon adsorption: Phsysicochemical treatment processes,. Totowa, New Jersey: Humana Press Inc., ( 2005), pp. 573-630.

8. IS-10200, Drinking water specification, Bureau of Indian Standards, 2012.

9. Jones H.R. (1974), Pollution Control in Dairy Industries. Noyes Data Corporation, Park, Ridge, New Jersey, (1974)

10. Kolhe, A.S., S.R. Ingale and R.V. Bhole, Effluents of Diary Technology, Int. Res. Jr. Sodh, Samiksha and Mulyankan, 5(II), (2009): 459-461.

11. Kushwaha JP, Srivastana C, Mall ID. An overview of various technologies for the treatment of dairy wastewaters. Critical Reviews in Food Science and Nutrition. Vol 51, (2011), pp-442- 452.

12. Khojare.A.S, A.B. Kadu, P.G. Wasnik, M.R. Patil and Mrs. B. A. Khojare, Adaptability of Membranes for Dairy Waste Management, Asian J. Exp. Sci., Vol. 19, No. 2, (2005), pp-105-112.

13. Karanth KR , "Groundwater assessment, development and management". Tata McGraw-Hill Publishing company Limited, New Delhi, India,(1997)

14. Landeka dragičević.T et al., The potential of diary wastewater, Mljekarstvo, vol- 60. (3), (2010), pp-191-197

15. Rao M, Bhole AG. Removal of organic matter from dairy industry wastewater using low-cost adsorbents. Journal of Indian Chemical Engineer. Section A, vol44 (1), (2002), pp-25-28. 